\title{
Creating Props: Improving Writing Skills of Teaching Materials of Elementary Teacher Education Students through Project-Based Learning Model
}

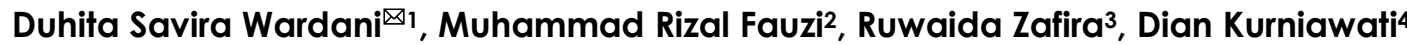 \\ 1,2, Elementary Education, IKIP Siliwangi, Cimahi, Indonesia \\ 3 Education Sciences, Tsukuba University, Tsukuba, Japan \\ 4 Applied Linguistics, The University of Sheffield, South Yorkshire, United Kingdom \\ $\bowtie$ duhita@ikipsiliwangi.ac.id
}

\begin{abstract}
This study aimed to determine the improvement in writing skills of science teaching materials for elementary school teachers students through the Project-Based Learning (PjBL) model. This study used a quasi-experimental method with One Group Pretest-Posttest Design using portfolio assessment sheets to write science teaching materials. Data were analyzed using a T-test. This study's subjects were pre-service teacher students who contracted Natural Science Learning courses in the Elementary Teacher Education Program. The study results indicated that $\mathrm{PjBL}$ could increase pre-service teachers' skills in developing teaching materials relevant to the 21 st-century skills, students' character, and the applicable curriculum. This result is evidenced by the results of the assessment, which increased significantly from 2.04 to 3.25. It is also based on the Wilcoxon test that Asymp.Sig. (2-tailed) $<0.05$ which is 0.000 . It means that there is an influence in the form of an increase in the PjBL model's use of the writing skills of science teaching materials for elementary teacher students. This study recommends that the PJBL model can be used as an alternative learning model to improve the writing skills of teaching materials for students.
\end{abstract}

Keywords: project-based-learning, writing skills, science teaching materials, pre-service teacher students, science props.

How to Cite: Wardani, D., Fauzi, M., Zafira, R., \& Kurniawati, D. (2020). Creating Props: Improving Writing Skills of Teaching Materials of Elementary Teacher Education Students through Project-Based Learning Model. Mimbar Sekolah Dasar, 7(2), 216-234. doi:https://doi.org/10.17509/mimbar-sd.v7i2.26334.

INTRODUCTION Teaching material is a set of learning tools or materials containing learning methods, methods, boundaries, and evaluations designed systematically and attractively to achieve the expected goals (Taqiyyah et al., 2017). Teaching material has an essential role in the learning process, namely, representing the teacher's explanation of students (Belawati, 2013). Good mastery of teaching materials can facilitate teachers in achieving learning goals. Conversely, teachers who do not master teaching materials cause learning to be less effective and interactive, so that learning objectives are challenging to achieve. Moreover, the current application of the 2013 curriculum, which requires education practitioners to develop 21 stcentury skills, makes teachers a key to the successful implementation of learning in class. Sunhaji (2016) explained the results of his research the suitability of a lesson plan designed by the teacher is the key to the students' success living in the community. This research shows that teachers' planning and use of suitable teaching materials can be the key to students' success in increasing knowledge. 
Duhita Savira Wardani et al., Creating Props: Improving Writing Skills...

National Education System Law No. 20 of 2003 Article 40 Paragraph 2 explains that the obligation of teachers in learning in the classroom should to create an educational atmosphere that is meaningful, creative, dynamic, and dialogic and has a professional commitment to improving the quality of education (Susilawati, Jannah, \& Dianasari, 2018). This system is part of professional competence that must be mastered by a teacher. When referring to the law, professional teachers are skilled in teaching materials and can write teaching materials. Students' needs and characteristics differ, so pre-service teachers need to be equipped to write teaching materials to create a useful and enjoyable learning atmosphere. This statement is supported by Rokhman \& Yuliati's (2010) research, which showed that teachers have the right to be creative in developing the relevant competence components, including in developing teaching materials. Indeed writing skills are a thought process because when a person writes, he must be prepared to face an unlimited number of revisions before his writing is published (Meiranti, 2012). In other words, writing skills can present the teacher's ideas and feelings related to the material in written form. Moreover, writing and reading form a strong relationship with each other as skills. They are tools for achieving effective written communication (Sadiku, 2015). Students need opportunities to develop their reading and writing skills. Developing students' reading and writing competencies require exposing students to gradually challenging reading materials and writing tasks. The aim is to make students read and write effectively.

The lack of teachers' ability to effectively display teaching materials is supported by teachers' lack of skills in making and writing teaching materials independently. Teaching materials that have been displayed by teachers in class are generally obtained from textbooks provided by the government or various publishers. Sometimes they do not follow the learning needs of students in their schools. It is because each school has a different culture and characteristics. Sukemi (2014), in his research, stated, "Based on the analysis of teachers' need, they need textbooks that are following the characteristics and needs of students in learning." However, many teachers do not have writing skills as expected. Sukerni's research was supported by Sinaga's (2015) study, which stated that the problem identified in the field study was teachers' low ability and skills in writing teaching materials. The number of books provided by the government for students is minimal (Abadi et al., 2017). On the other hand, the development of natural science material has also not been applied by teachers following students' character and needs in their daily lives. Therefore, a pre-service teacher needs to be equipped with writing skills to arrange and develop the ability to write teaching materials to understand knowledge with the science process better.

One alternative that can be applied to improve pre-service teachers' writing skills is to use a Project-Based Learning (PjBL) model. PjBL can facilitate pre-service teachers to write teaching materials to align with the expected learning objectives. Wekesa \& Ongunya (2016) argue that 
$\mathrm{PjBL}$ is a teaching technique that changes learning from "teacher storytelling" to "students doing" where students are given assignments based on challenging questions or problems that involve students in problem-solving, decision making, understanding, investigative skills, and reflection. Tiantong \& Sumalee Siksen (2013) stated that PJBL is useful for increasing student learning achievement, acquiring knowledge through active learning, and gaining interdisciplinary and multidisciplinary knowledge. From the two opinions above, it can be concluded that the PjBL model can enhance various skills and provide active learning experiences through various activities. Through PjBL, it is hoped that the writing skills of teaching materials for pre-service elementary school teachers will improve and become better so that the quality of learning obtained is in line with national education's objectives.

One form of activity in the PJBL model in the Science Base Concept course is making science props. The need for visual props in science is based on the fact that some science material contains abstract principles, concepts, and theories, such as energy, light, waves, and electricity (Rohim et al., 2012). Teaching props are expected to help in the study of science to deliver concepts that become meaningful. Prasetyarini, Fatmaryanti, and Akhdinirwanto (in Saputri \& Dewi, 2014) stated that learning by using teaching props is a series of activities to convey learning material that aims to provide opportunities for students to actively learn to enable students to gain knowledge and develop psychomotor skills and foster student creativity to solve the problems faced.

Research on implementing the PjBL model in learning to improve writing skills has not been carried out in Indonesia. Some research on the PjBL model is still in the form of model studies or learning processes that can build skills other than writing skills. These studies are Ralph (2015) that there is a positive connection between content knowledge learning and PJBL in collaborative settings on the post-secondary institution. Meanwhile, Bilgin et al. (2015) investigate the effects of the Project-Based Learning (PjBL) method on undergraduate students' achievement and its association with these students' self-efficacy beliefs about science teaching and pinions about PjBL. Tseng et al. (2013) combined PjBL with STEM to increase effectiveness, generate meaningful learning, and influence student attitudes in future career pursuit. Students are positive towards combining PjBL with STEM. Unlike previous studies, this research focused on improving writing skills on teaching material by creating science props through PjBL in science.

Based on the description, the researcher focused this study on "Improving Writing Skills of Teaching Materials of Elementary Teacher Education Students Through Project-Based Learning Model With Creating Science Props Activities." This study aims to determine the effectiveness of $\mathrm{PjBL}$ in improving Elementary Teacher Education students' science writing skills by creating science props activity. PjBL is hoped that pre-service elementary school teachers' writing skills 
Duhita Savira Wardani et al., Creating Props: Improving Writing Skills...

will be better to write teaching materials independently. That way, the quality of learning obtained is following the goals of national education.

\section{LITERATURE REVIEW}

\section{Project-Based Learning}

Project-based learning is a student-centered learning model and provides meaningful learning experiences (Afriana et al., 2016). Student learning experiences and concept acquisition are built on the products produced in the project-based learning process. Project-based learning models can help students develop creativity through project-based problem-solving activities. Özer \& Özkan (2012) stated that the project-based learning model is considered an excellent learning model in developing various necessary skills that students must possess, such as decision-making skills and creative problem-solving other process skills. PjBL can also improve pre-service teachers' writing skills in terms of quality of content, language, and presentation (Susilawati et al., 2018).

The PjBL stages in this research adapt from the PjBL stages of Doppelt (2005), namely: 1) Design purpose, which is defining the problem, 2) Field Inquiry, which defines the aspects of inquiry in the scope of the problem, 3) Alternative Solution, which involves considering alternative solutions to problems, formulated, 4) Choosing the Preferred Solution, namely choosing the right or best solution, 5) Operation Step, which is planning an operational method to implement the chosen solution, and 6) Evaluation, which is to evaluate the entire process and product produced.

\section{Writing Skills on Science Teaching Material}

Writing skills are one of the language skills that need to be trained by a person in order to be able to present the ideas intended by the author. According to Mujiyono et al. (2014), writing skills are a person's ability to express thoughts, ideas, ideas using a series of written language that is good and correct. A person's skills or abilities are derived from his ability to hear, speak, and read. The information obtained for writing will go in and out through the process of listening, speaking, and reading. Writing skills have various benefits for a person. Writing activities involve a communication transformation process that is processed into writing ideas. It involves a thought process that is not simple so that students are more creative, skilled, and dare to convey the information and ideas they have obtained (Susilawati et al., 2018).

The skill of writing science teaching materials is closely related to the subject matter in the form of facts, principles, procedures, and attitudes that must be mastered by the teacher, which is then adjusted to the character and needs of students and is relevant to the applicable curriculum. The science learning process emphasizes providing direct experience to students 
to develop various competencies in order to be able to explore and understand the natural surroundings scientifically (Hwang et al., 2007). Besides, the immediate environment has a higher meaning than observing phenomena far from the student's environment. Therefore, in $\mathrm{PJBL}$ learning, it is directed to obtain science teaching materials so that their relevance is high according to student needs.

\section{Pre-service Teacher Students}

The definition of a pre-service teacher can be explained as someone who is currently studying at the Teaching and Education Institute so that he is eligible to become an elementary teacher following statutory regulations (Susilawati et al., 2018). Pre-service elementary school teachers need to be equipped with various knowledge and skills to be their job, namely an educator, theoretically and applicatively (Savolainen et al., 2012). One of them is writing teaching materials, which is part of his task, namely compiling the teaching materials used for the learning process (Santagata et al., 2007).

Bleicher (2004) stated that the skills to write teaching materials need to be given to pre-service teachers as a provision for carrying out their primary duties and functions as an educator. Teaching materials need to be prepared by the teacher independently. Therefore, the process of practicing writing skills needs to be done continuously.

\section{METHOD}

\section{Research Design}

The research method used in this study was a pre-experimental with One Group Pretest-Posttest Design. Researchers used the One Group Pretest-Posttest design because the sample experienced obstacles and limitations, both in determining the sample, the study's location, and the limited time. However, from several obstacles that exist, researchers are trying to minimize failures during the study. The researcher also did not generalize the research results on students outside the study population used when the research was conducted. This study's results were only for elementary school students at the tertiary educational institution where the research was conducted. The One Group Pretest-Posttest design can be seen in Figure 1.

\section{$\mathrm{O}_{1} \times \mathrm{O}_{2}$}

Figure 1. Pre-experimental research design Single-One Group Pretest-Posttest

Note:

$\mathrm{O}_{1}$ : pretest writing skills

$\mathrm{O}_{2}$ : posttest writing skills 
Duhita Savira Wardani et al., Creating Props: Improving Writing Skills...

\section{Research Procedure}

In this design, the sample is first given a pretest to determine the students' initial writing science teaching materials before being given treatment. Then students are given treatment in the form of learning using PjBL to make science teaching aids. After being given treatment, at the end of learning, students are given a test (post-test) to determine the final ability of students in writing science teaching materials, so the immense influence of PjBL with the activity of making science teaching aids on students' writing skills is $\left(\mathrm{O}_{2}-\mathrm{O}_{1}\right)$.

\section{Participants}

The study was conducted at one of the educational colleges at Cimahi, West Java. The study population was selected by random sampling from pre-service elementary teacher students who contracted the "Science Learning" course in the 5th-semester Elementary Teacher Education Study Program. Characteristics of participating students were: 1) students have contracted the "science learning" course so that they already have prior knowledge of the science of science, 2) 5th-semester students have entered the middle and final stages of study so that writing skills are needed when they will start an apprenticeship program in elementary schools. The variables studied were Project Based Learning (PjBL) as the independent variable and the science writing skills of teaching materials as the dependent variable.

\section{Instruments and Data Analysis Technique}

The instruments used in this study were portfolio sheets and observation sheets. Due to the time this research took place during the COVID 19 pandemic, this research was carried out in virtual or online learning from June until July. Furthermore, the data obtained in this study were processed and analyzed using descriptive statistical techniques, including averages, standard deviations, maximum values, and minimum values. Assessment of pre-service elementary teacher students' skills in preparing science teaching materials based on various criteria, namely content eligibility, the feasibility of presentation, and language eligibility. Furthermore, the writing skills data of elementary school teacher candidates were categorized quantitatively based on the categorization technique based on the formula:

$$
\text { avarage value }=\frac{\sum \text { score obtained }}{3}
$$

Then, the results of processing scores on elementary school teacher candidates' writing skills are classified by the assessment criteria, as in Table 1.

Table 1. Criteria for Evaluation of Writing Skills in Teaching Materials for Pre-service Teacher Teachers

\begin{tabular}{cll}
1 & Score Range & Criteria \\
\hline 1 & $3.01<$ score $\leq 4.00$ & Skilled \\
2 & $2.01<$ score $\leq 3.00$ & Sufficiently skilled
\end{tabular}




$\begin{array}{lll}3 & 1.01<\text { score } \leq 2.00 & \text { Less skilled } \\ 4 & 0<\text { score } \leq 1,00 & \text { Not skilled }\end{array}$

(Source: Adapted Ratumanan, G. T., \& Laurens, 2011)

Moreover, in this data processing activity, a T-Test (paired sample t-test) was used to determine whether there was an effect of the PBL learning on improving the writing skills of science teaching materials for elementary school teacher candidates. Form the hypothesis if the Asymp.Sig value. (2-tailed) $>\mathrm{a}$, where $\mathrm{a}=0.05$; then $\mathrm{HO}$ is accepted and interpreted as not having a significant improvement in the writing skills of science teaching materials for elementary school teacher candidates using the Project-Based Learning (PjBL) model.

\section{RESULTS}

\section{Effectiveness of Project-Based Learning (PjBL) on Improvement of Writing Skills for Natural Science Teaching Materials for Primary Teachers}

\section{Results of the Dropper before the Implementation of the PJBL}

The pretest was carried out at the beginning of learning before implementing PjBL, namely on Monday, June 9, 2020, and Wednesday, June 11, 2020. At this meeting, students did not understand the real concept of teaching materials. From the pretest of 40 students' results, the average value of the indicator on the content's feasibility was 1,77 . The average value of the indicator on the presentation's feasibility was 1,81, and the average value of the indicator of language feasibility was 1,81 . Thus, the average score on teaching materials' writing skills is 1,80 with the category of "quite skilled." This data can be seen in Figure 2.

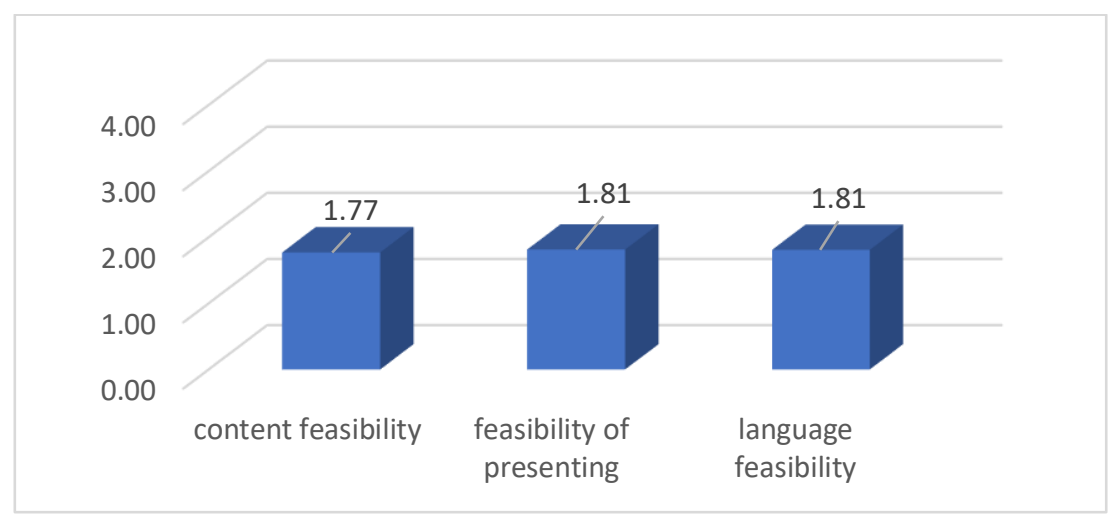

Figure 2. Average Test Pretest Skills in Teaching Material

After knowing each indicator's pretest value, the next step is to add the value for each indicator, and the final pretest value is obtained. The final value of the pretest was analyzed using Microsoft Excel 2010. The analysis of the results can be seen in Table 3.

Table 3. Results of Data Analysis Pretest Writing Skills for Teaching Materials

\begin{tabular}{lc} 
Statistics & Value Pretest Statistics \\
\hline Sample & 40
\end{tabular}


Duhita Savira Wardani et al., Creating Props: Improving Writing Skills...

$\begin{array}{ll}\text { Minimum Value } & 1,33 \\ \text { Maximum Value } & 3,00 \\ \text { Average Value } & 1,80 \\ \text { Standard Deviation } & 0,31\end{array}$

Based on Table 3, it can be concluded that from 40 students, the minimum score on the pretest results was 1.83 (less skilled category). In comparison, the average pretest results are 2.04 (the category of skilled enough) and the standard deviation of 0.18. Also, the frequency of obtaining pretest assessment skills in writing science teaching materials for elementary school teacher candidates can be seen in Table 4.

Table 4. Frequency of Results of Pretest Writing Skills for Teaching Materials

\begin{tabular}{clcc} 
Value & Category & Frequency & Percentage \\
\hline $3.01-4.00$ & Skilled & 1 & $3 \%$ \\
$2.01-3.00$ & Sufficiently skilled & 20 & $50 \%$ \\
$1.01-2.00$ & Less skilled & 19 & $47 \%$ \\
$0.00-1.00$ & Not skilled & 0 & $0 \%$ \\
& Total & 40 & $100 \%$
\end{tabular}

\section{Implementation of Treatment using PjBL}

After carrying out the pretest, the next step is to carry out treatment using PJBL 3 times on Monday 15, 22, and 29 June 2020. This treatment is carried out following the PJBL learning steps, as shown in Table 5.

Table 5. PjBL Steps in Class
Numb.
PjBL Stages
Implementation

$\begin{array}{ll}1 \text { Design Purpose is defining the } & \text { At this stage, students conduct discussion } \\ \text { problem } & \text { activities related to learning problems in } \\ & \text { elementary school. These problems } \\ & \text { include learning that is presented as less } \\ & \text { effective and interactive. Besides, learning } \\ & \text { objectives are more difficult to achieve by } \\ & \text { students, especially in learning science. In } \\ & \text { this step also, students limit learning } \\ & \text { problems that originate from teaching } \\ & \text { materials. }\end{array}$

2 Field Inquiry is defining aspects of

Students carry out this step by analyzing inquiry within the scope of the the problem of science teaching problem materials. The various problems related to the cause are analyzed whether they come from students, teachers, or the 
Implementation

government. At this stage also, students get several questions related to the teacher's low ability to prepare teaching materials, which causes learning in the classroom to be less effective.

3 Propose alternative solutions to problems that involve considering alternative solutions to the problem being formulated
Students' stages in this step are with several alternative solutions to the problem that must be solved. Students as pre-service teachers discuss the understanding of teaching materials and analyze various ways to be able to arrange teaching materials, including by analyzing models of teaching material development, namely the "ASSURE" and "ADDIE" models. Based on these models, students study the alternatives that make it most comfortable compile teaching materials simply.

4 Choosing the Preferred Solution is to choose one right alternative solution
Based on the previous step, this step is carried out by students by selecting the "ASSURE" model as a step to compile science teaching materials following the curriculum and student needs. The natural science materials arranged in teaching materials are based on the material in the 2013 curriculum but are still written based on the subject matter of science. Besides, as writing training materials, pre-service teacher students use the topic of "movement and energy" that exist in class 4 to be made teaching materials to facilitate students in preparing contextual teaching materials and following with students' needs in elementary school. 
Duhita Savira Wardani et al., Creating Props: Improving Writing Skills...
Numb.
PjBL Stages
Implementation

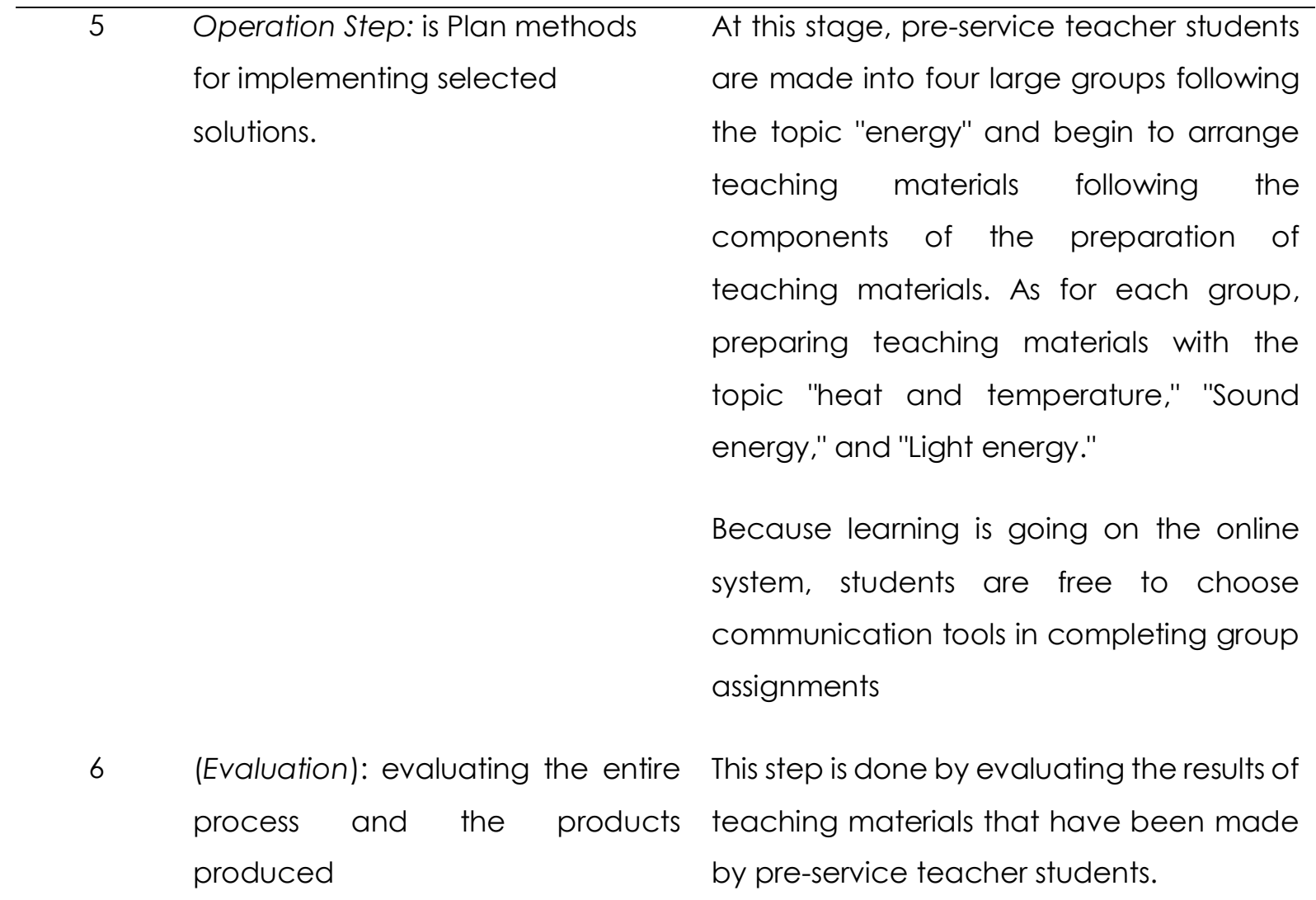

\section{Posttest Results After the Implementation of PjBL}

Posttest was carried out after the PjBL treatment, namely on Wednesday, July 1, 2020, and Friday, July 3, 2020. The post-test results were seen from each indicator of the textbook's writing skills, namely the appropriateness of the content, the language's appropriateness, and the presentation's appropriateness. The results of the average value of the feasibility of the contents are 3.41 (skilled categories), the feasibility of presentation is 3.36 (skilled categories), and the average value of language feasibility is 3.40 (skilled categories).

If seen from the average post-test score results, it is seen an increase in each indicator. The feasibility of contents increased by 1,64 , the feasibility of presentation increased by 1.55 , and the language's feasibility increased by 1.59. A more significant increase was seen in the language feasibility indicators. Obtaining the pretest and post-test writing skills of the elementary student's teaching materials can be seen in Figure 3. 


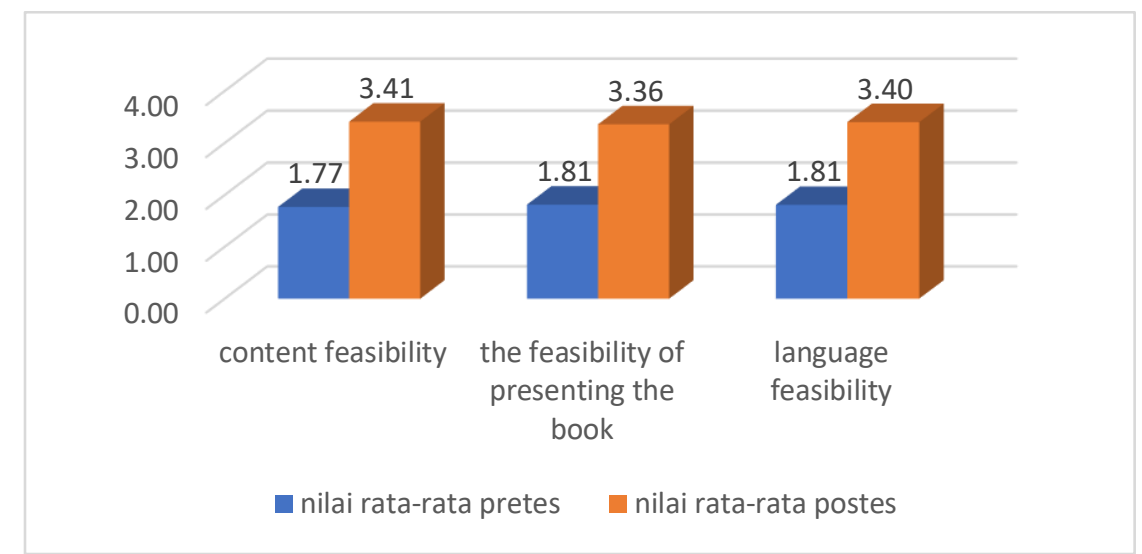

Figure 3. Average Test Pretest Skills in Teaching Material

Then the results of the post-test can be analyzed using Microsoft Excel 2010. The results of the analysis can be seen in Table 6 .

Table 6. Results of Post-Data Data Analysis Skills for Writing Teaching Materials

\begin{tabular}{lc} 
Statistics & Value of Post-test Statistics \\
\hline Sample & 40 \\
Minimum Score & 3.07 \\
Maximum Score & 4,00 \\
Average Score & 3,39 \\
Deviation Standard & 0,15
\end{tabular}

Based on Table 6, it can be concluded that the average post-test results of teaching material writing skills are 3.48 (skilled category), the minimum value is 3.25 (skilled category), the maximum value is 4.00 (skilled category), and the standard deviation has amounted to 0.15 . The frequency of post-test assessment of the writing skills of science teaching materials for preservice teacher students can be seen in Table 7.

Table 7. Frequency of Posttest Results Writing Skills for Teaching Materials

\begin{tabular}{clcc}
\hline Value & Category & Frequency & Percentage \\
\hline $3,01-4,00$ & Skilled & 40 & $100 \%$ \\
\hline $2,01-3,00$ & Sufficiently skilled & 0 & $0 \%$ \\
\hline $1,01-2,00$ & Less skilled & 0 & $0 \%$ \\
\hline $0,00-1,00$ & Not skilled & 0 & $0 \%$ \\
\hline & Total & 40 & $100 \%$ \\
\hline
\end{tabular}

Wilcoxon Test Results from The Effect of Project-Based Learning (PjBL) on Improving the Writing Skills of Natural Science Teaching Materials for Pre-service Teachers

After knowing the pretest and post-test scores of elementary school teacher candidates' writing skills, the next step is to do the t-test with a paired sample t-test. However, because the research data is not normally distributed, the test used in this study is the Wilcoxon test or also called the Wilcoxon Signed Rank Test. This test is conducted to determine whether there is an 
Duhita Savira Wardani et al., Creating Props: Improving Writing Skills...

increase or effect of the PjBL model (variable $\mathrm{x}$ ) on the skills of writing science teaching materials (variable y) of elementary school teacher candidates. The results of data processing using SPSS 20 can be seen in Table 9.

Table 9. Ranks Results

Ranks

\begin{tabular}{|c|c|c|c|c|}
\hline & & $\mathrm{N}$ & Mean Rank & Sum of Ranks \\
\hline \multirow{4}{*}{ Post - Pre } & Negative Ranks & $0^{\mathrm{a}}$ & .00 & .00 \\
\hline & Positive Ranks & $40^{\mathrm{b}}$ & 20.50 & 820.00 \\
\hline & & $0^{c}$ & & \\
\hline & Total & 40 & & \\
\hline
\end{tabular}
a. Pos < Pre
b. Pos $>$ Pre
c. Pos $=$ Pre

Negative ranks between writing skills for pretest and post-test are 0 (zero), both in N's value, mean Rank, and Sum Rank. This 0 (zero) value indicates no decrease (reduction) from the pretest value to the post-test value. Then the positive ranks or the difference (positive) between the writing skills of teaching materials for pretest and post-test. In Table 10, it can be seen that there are 40 positives $(\mathrm{N})$ data, which means that 40 students have increased writing skills in teaching materials from pretest to post-test scores. Whereas Ties are the similarity of pretest and post-test values. Ties value 0 (zero) indicates that there is no similar value between pretest and post-test. Then for the "Test Statistics" output can be seen in Table 10.

Table 10. Output Results

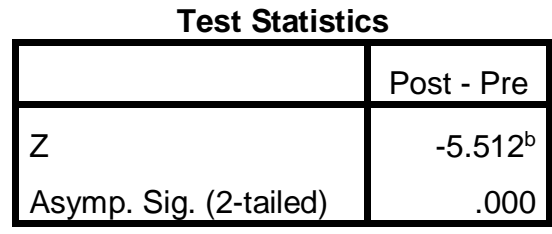
a. Wilcoxon Signed Ranks Test
b. Based on negative ranks.

Based on Table 1 1, it is known as Asymp.Sig. (2-tailed) worth 0,000. Because the value is 0,000,05, it can be concluded that $\mathrm{HO}$ is rejected and $\mathrm{Hl}$ is accepted. This means that there is a difference between the writing skills of student teaching materials for pretest and post-test, so it can be concluded that "there is an influence in the form of an increase in the use of the Project-Based Learning (PjBL) model on the writing skills of science teaching materials for elementary education pre-service teacher students." 


\section{DISCUSSION}

Figure 2 shows that the indicator of content feasibility gets the lowest average pretest value than the indicator of the feasibility of presentation and language feasibility. In the indicator of content feasibility, elementary school teacher students get an average score of 1,77 in the less skilled category. Students already understand the content of material relevant to the applicable curriculum, namely the 2013 Curriculum, so that the instructional materials compiled are following with Basic Competencies (KD) and Core Competencies (KI). However, the material compiled is still not contextual, so it is not relevant to elementary school students' needs and characteristics. The material compiled is still general and superficial, meaning that students do not fully understand the concept of the material written. The concept that is not fully understood by students is because lectures that take place so far are only in the form of lectures that do not require students to be active in asking questions or expressing opinions, making observations, discussions, analyzing and applying concepts and ideas in a learning activity to cause students to be unable solve more complex problems. This kind of learning does not require students to think critically in solving daily life problems (Sinaga, 2015).

While the presentation's feasibility indicator gets an average value of 1,81 in the less skilled category, this is due to some students already understanding how to present suitable teaching materials, as evidenced by some students who have shown values above 3 in this aspect. Nevertheless, many students do not write the introduction at the beginning, sample problems, worksheets, and summaries of each lesson presented in teaching materials. These students still tend to make their material teaching concepts without seeing various aspects of every learning. Besides, the use of images as illustrations supporting material in teaching materials is still very minimal. According to Daryanto (2016), students tend not to like textbooks, especially those that are not accompanied by exciting pictures and illustrations; students tend to like picture books full of colors and are visualized in natural forms or picture illustrations.

Then in the language feasibility indicator, the pretest average is 1,81 with the category of less skilled. Several students have shown good grades in straightforward, communicative, dialogic, and interactive aspects. However, it still lacks conformity with students, conformity with Indonesian language rules, and consistent use of terms, symbols, and icons. The written language used in teaching materials of most students is still not following the age level of elementary school students, so that it will be difficult to understand and less stimulating students to question something further. Simultaneously, sentence structures must be under the level of language mastery and the level of cognitive development of students (Depdiknas, 2011). Relating to conformity with the Indonesian language rules, Solchan (2014) explains that textbooks must use correct and standard language and use standardized transliteration. Similarly, terms that describe a concept must be consistent between sections in the book 
Duhita Savira Wardani et al., Creating Props: Improving Writing Skills...

because using consistent terms will make it easier for students to understand the reading content (Purnanto, 2018).

After applying PjBL, the average value of the indicator of content feasibility is obtained, which is 3.41 with the skilled category. The average post-test score increased by 1.64 from the previous average pretest score of 1,77 . Students have a much better understanding of the concept of natural science material in elementary schools after conducting lectures by applying PjBL. PjBL organizes learning in projects and engages students in authentic situations where students can apply learning material to complex and relevant problems with skills that follow the times' demands (Chiang \& Lee, 2016). PjBL can also increase students' desire to learn (Astawa et al., 2017). The successful implementation of PJBL in class can increase student motivation by being fully involved in classroom activities. This result is supported by Wan Husin et al. (2016) that the level of 21 st-century skills among the students increased, and the increase was statistically significant by implementing PjBL.

One of the activities that can involve students in being active in lectures is teaching props. Making and using teaching props in learning can help instill and understand science concepts or principles. By operating props, materials, or abstract things in science can be presented in models. In the form of concrete objects can be manipulated and developed to be easily understood by students (Annisah, 2014).

Making and using teaching props by students in learning activities can increase student motivation and develop knowledge, skills, and basic needs in the delivery of material, concepts, and information in the learning process at school (Oktafiani et al., 2017; Alvian et al., 2017; Maretasari et al., 2012). Thus, PjBL learning with the activity of making teaching props will increase students' understanding of elementary school science concepts being studied. The average value on the indicator of the feasibility of the contents of student teaching materials can increase.

After students are actively involved in making teaching props, students are then assigned individually to write independent teaching materials that contain science materials based on teaching props that have been made by each group. Before being allowed to write, lecturers or researchers first explain how to write suitable teaching materials, including indicators of content eligibility, presentation eligibility, and language eligibility. The appropriateness of the contents relates to how students understand their respective cognitive schemes of teaching materials in the form of facts, concepts, laws, and principles, which are then poured into written form. The feasibility of the presentation relates to the physical and systematic form of writing the instructional material that is made, for example, writing an introduction at the beginning, sample questions, worksheets, and summaries of each lesson presented in the teaching material, and the use of graphics and illustrations accordingly. Whereas the language's 
feasibility relates to aspects of the language used in teaching materials, for example, straightforwardness, the effectiveness of sentences, the accuracy of words, communicative, dialogic and interactive, conformity with student characteristics, and conformity with Indonesian rules. According to Nurhadi (2017), writing is a mechanistic skill, meaning that it cannot be mastered only through theory. Therefore, it is necessary to gradually and continuously practice writing exercises because writing is a skill being trained (Langan, 2011). Training students to write teaching materials independently means they have also trained students in the thought process because writing is how a person communicates his thoughts and feelings to be understood by himself and others, especially related to a science concept (Indrilla \& Ciptaningrum, 2018). This exercise then impacts the average post-test score on indicators of the feasibility of presentation and the feasibility of language, which is improved. It is supported by the study of Sadeghi et al. (2016) that implemented PJBL on Iranian EFL learner comparison/contrast paragraph writing skills. The results were submitted to the t-test, revealing the students who were educated by PBL outperformed the students who were educated by the instruction based on student textbooks. The findings lend credence to the positive effects of PBL in enhancing students writing performance.

\section{CONCLUSION}

Based on the research carried out and the results of data analysis that has been done, it can be concluded that there is an increase in learning with the PJBL model to improve the writing skills of teaching materials for pre-service elementary school teachers. This fact is evidenced by the results of the assessment of pretest and post-test. It is increased significantly on each indicator. Content feasibility increased by 1,77 , the feasibility of presentation increased by 1,55 , and the language's feasibility increased by 1,59. It is supported by the Wilcoxon Test results for pretest and post-test data, which are worth 0,000 . Because the value of $0,000<0.05$, it can be concluded that $\mathrm{H}_{0}$ is rejected and $\mathrm{H}_{1}$ is accepted. This means that there is a difference between the writing skills of student teaching materials for pretest and post-test, so it can be concluded that "there is an influence in the form of an increase in the use of the PJBL model on the writing skills of science teaching materials for the prospective elementary school teacher."

\section{ACKNOWLEDGMENTS}

We would like to thank friends who give comments and suggestions regarding the statistical data analysis. We also would like to thank the Directorate General of Higher Education Ministry of Education dan Culture for funding this research. This research was conducted for Elementary Teacher Education Department.

\section{REFERENCES}

Abadi, M. K., Pujiastuti, H., \& Assaat, L. D. (2017). Development of Teaching Materials Based Interactive Scientific Approach towards the Concept of Social Arithmetic for Junior High 
Duhita Savira Wardani et al., Creating Props: Improving Writing Skills...

School Student. Journal of Physics: Conference Series. 812012015. https://doi.org/10.1088/1742-6596/812/1/012015.

Afriana, J., Permanasari, A., \& Fitriani, A. (2016). Implementation of STEM integrated project based learning to improve students' scientific literacy in terms of gender. Journal of Science Education Innovation, 2(2), 202-212. https://doi.org/10.21831/jipi.v2i2.8561.

Alvian, A., Yulianto, A., \& Subali, B. (2017). Design of Digital Image Creator For Optical Microscope (DIGICOM) Teaching Tool in Science Learning to Foster Student Motivation. UPEJ Unnes Physics Education Journal. 6(3), 32-37. https://doi.org/10.15294/UPEJ.V613.19312

Annisah, S. (2014). Mathematics Learning Teaching Aids. Tarbawiyah Journal, 11(1), 1-15. https://e-journal.metrouniv.ac.id/index.php/tarbawiyah/article/view/356.

Astawa, N. L. P. N. S. P., Artini, L. P., \& Nitiasih, P. K. (2017). Project-based Learning Activities and EFL Students' Productive Skills in English. Journal of Language Teaching and Research. 8(6), 1147-1155. https://doi.org/10.17507/jltr.0806.16.

Bilgin, I., Karakuyu, Y., \& Ay, Y. (2015). The effects of project based learning on undergraduate students' achievement and self-efficacy beliefs towards science teaching. Eurasia Journal of Mathematics, Science and Technology Education. 11(3), 469-477. https://doi.org/10.12973/eurasia.2014.1015a.

Chiang, C. L., \& Lee, H. (2016). The Effect of Project-Based Learning on Learning Motivation and Problem-Solving Ability of Vocational High School Students. International Journal of Information and Education Technology. 6(9), 709-712. https://doi.org/10.7763/ijiet.2016.v6.779.

Daryanto. (2016). Media Pembelajaran Edisi Ke 2 Revisi (Learning Media Second Edition Revision). Yogyakarta: Gava Media.

Doppelt, Y. (2005). Assessment of project-based learning in a Mechatronics context. Journal of Technology Education. 16(2), 7-12. https://doi.org/10.21061/jte.v16i2.a.1.

Hwang, W. Y., Chen, N. S., Dung, J. J., \& Yang, Y. L. (2007). Multiple representation skills and creativity effects on mathematical problem solving using a multimedia whiteboard system. Journal of Educational Technology \& Society, 10(2), 191-212. https://www.jstor.org/stable/pdf/jeductechsoci.10.2.191.pdf.

Indrilla, N., \& Ciptaningrum, D. S. (2018). an Approach in Teaching Writing Skills: Does It Offer a New Insight in Enhancing Students' Writing Ability. Journal: A Journal on Language and 
Language Teaching. 21 (2). 124-133. https://doi.org/10.24071/llt.2018.210201

Langan, J. (201 1). College Writing Skills with Reading (8th Edition). New York: McGraw Hill.

Maretasari, E., Subali, B., \& Hartono. (2012). The Application Of Guided Inquiry Learning Models And Students' Scientific Attitudes. Unnes Physics Education Journal. 1(2), 27-31. https://doi.org/10.15294/upej.v1i2.1375.

Meiranti, R. (2012). Improving Students' Writing Skills Through Field Trip Method. English Review: $\begin{array}{llll}\text { Journal of English } & \text { Education. }\end{array}$ https://journal.uniku.ac.id/index.php/ERJEE/article/view/73

Monchai Tiantong \& Sumalee Siksen. (2013). The online project- based learning model based on student's multiple intelligence. International Journal of Humanities and Social Science. 3(7), 204-21 1.http://www.ijhssnet.com/journals/Vol_3_No_7_April_2013/23.pdf.

Mujiyono, Suyanto, E., \& Samhati, S. (2014). Development of Writing Teaching Materials Based on Islamic Character Values for Tsanawiyah Junior High School. J-Simbol (Bahasa, Sastra, Dan Pembelajarannya), 2(1), 1-18. http://jurnal.fkip.unila.ac.id/index.php/BINDO/article/view/7655.

Nurhadi. (2017). Handbook of Writing. Jakarta: Bumi Aksara.

Oktafiani, P., Subali, B., \& Edie, S. S. (2017). Development Of A Multipurpose Optical Kit (AP-KOS) Teaching Aid To Improve Science Process Skills. Journal of Science Education Innovation. 3(3), 189-200. https://doi.org/10.21831/jipi.v3i2.14496.

Özer, D., \& Özkan, M. (2012). The Effect of the Project Based Learning on the Science Process Skills of the Prospective Teachers of Science. Journal of turkish Science Eduction. 9(3), 131136. https://www.semanticscholar.org/paper/The-Effect-of-the-Project-Based-Learningon-the-of-\%C3\%96zer-\%C3\%96zkan/44b5dcfa89e8aa3eal cfbd9cee81770bfb8c9e4a.

Ralph, R. A. (2016). Post secondary project-based learning in science, technology, engineering and mathematics. Journal of Technology and Science Education. 6(1), 1-10. https://doi.org/10.3926/jotse.155

Ratumanan, G. T., \& Laurens, T. (2011). Assessment of Learning Outcomes at the Education Unit Level 2. Surabaya: Unesa University Press.

Rohim, F., Susanto, H., \& Ellianawati. (2012). Application Of The Guided Discovery Model To Learning Physics To Improve Creative Thinking Ability. UPEJ (Unnes Physics Education Journal). 1(1), 1-5. https://doi.org/10.15294/upej.v1i1.775. 
Duhita Savira Wardani et al., Creating Props: Improving Writing Skills...

Rokhman, F., \& Yuliati. (2010). The development of the Indonesian teaching material based on multicural context by using sociolinguistic approach at junior high school. Procedia - Social and Behavioral Sciences. 9 (2010) 1481-1488 https://doi.org/10.1016/j.sbspro.2010.12.353.

Sadeghi, H., Biniaz, M., \& Soleimani, H. (2016). The Impact of Project-Based Language Learning on Iranian EFL Learners Comparison/Contrast Paragraph Writing Skills. International Journal of Asian Social 6cience. 510): 524 . https://doi.org/10.18488/journal.1/2016.6.9/1.9.510.524

Sadiku, L. M. (2015). The Importance of Four Skills Reading, Speaking, Writing, Listening in a Lesson Hour. European Journal of Language and Literature. 1(1), 29-31. https://doi.org/10.26417/ejls.v1i1.p29-31.

Santagata, R., Zannoni, C., \& Stigler, J. W. (2007). The role of lesson analysis in pre-service teacher education: An empirical investigation of teacher learning from a virtual videobased field experience. Journal of Mathematics Teacher Education. 10, 123-140(2007). https://doi.org/10.1007/s10857-007-9029-9.

Saputri, V. A. C., \& Dewi, N. R. (2014). Development Of Simple Visual Aids With The Eye Theme Of Class VIII To Foster Students' Skills. Jurnal Pendidikan IPA Indonesia (Journal of Indonesian Science Education). 3(2), 109-1 15. https://doi.org/10.15294/jpii.v3i2.3108.

Savolainen, H., Engelbrecht, P., Nel, M., \& Malinen, O. P. (2012). Understanding teachers' attitudes and self-efficacy in inclusive education: Implications for pre-service and inservice teacher education. European Journal of Special Needs Education. 27(1), 51-68. https://doi.org/10.1080/08856257.2011.613603.

Sinaga, P. (2015). Desain Model Pembelajaran untuk Meningkatkan Keterampilan Calon Guru Fisika dalam Menulis Materi Ajar (Learning Model Design to Improve the Skills of Prospective Physics Teachers in Writing Teaching Materials). Prosiding Seminar Nasional Fisika (E-Journal) (Proceedings of the National Physics Conference) SNF2015, Volume IV, Oktober 2015. http://journal.unj.ac.id/unj/index.php/prosidingsnf/article/view/4796.

Solchan. (2014). Pendidikan Bahasa Indonesia di SD (Indonesian Language Education in Elementary Schools). Jakarta: Universitas Terbuka.

Sukerni, P. (2014). Development Of Class Iv Science Education Teaching Book Semester I Sd No. 4 Kaliuntu With Dick And Carey Model. JPI (Jurnal Pendidikan Indonesia). 3(1), 386-396. https://doi.org/10.23887/jpi-undiksha.v3i1.2920.

Sunhaji. (2016). The Implementation of Integrated Learning in the Islamic Religion Education as to Grow the Religiosity and Faith of Learners. International Journal of Humanities and 
Social

Science.

6(11),

279-289.

https://www.ijhssnet.com/journals/Vol_6_No_11_November_2016/31.pdf.

Susilawati, Jannah, W. N., \& Dianasari. (2018). The Effectiveness Of Project Based Learning On The Skills Of Writing Ipa Teaching Materials Prospective Teachers. EduHumaniora - Jurnal Pendidikan Dasar Kampus Cibiru. 10(1), 38-49. https://doi.org/10.17509/eh.v10i1.8871

Taqiyyah, S. A., Subali, B., \& Handayani, L. (2017). Implementation Of Metacognitive-Based English Science Teaching Materials To Improve The Problem Solving Abilities Of Junior High School Students. Journal of Science Education Innovation. 3(2), 225-234. https://doi.org/10.21831/jipi.v3i2.14859

Tseng, K. H., Chang, C. C., Lou, S. J., \& Chen, W. P. (2013). Attitudes towards science, technology, engineering and mathematics (STEM) in a project-based learning (PjBL) environment. International Journal of Technology and Design Education. 23:87-102. https://doi.org/10.1007/s10798-011-9160-x

Wan Husin, W., Mohamad Arsad, N., Othman, O., Halim, L., Rasul, M., Osman, K., \& Iksan, Z. (2016). Fostering Students' 21st Century Skills through Project Oriented Problem Based Learning (POPBL) in Integrated STEM Education Program. Asia-Pacific Forum on Science Learning and Teaching. 11(1), Article 3 (Jun., 2016). https://eric.ed.gov/? id=EJ1113235.

Wekesa, N. W., \& Ongunya, R. O. (2016). Project Based Learning on Students' Performance in the Concept of Classification of Organisms among Secondary Schools in Kenya. Journal of Education and Practice. 7(16), 25-31. https://files.eric.ed.gov/fulltext/EJ1 105278.pdf. 